\title{
Model Pemberdayaan Santri Podndok Pesantren Al-Furqon Kota Prabumulih Melalui Kewirausahaan
}

\author{
${ }^{1 *}$ Rudy Kurniawan, ${ }^{2}$ Andries Lionardo \\ ${ }^{1,2}$ Fakultas Ilmu Sosial dan Ilmu Politik, Universitas Sriwijaya, Palembang, Indonesia
}

\begin{abstract}
Penelitian ini berjudul "Pemberdayaan Santri Podndok Pesantren al-Furqon Kota Prabumulih Melalui Kewirausahaan" bertujuan untuk menemukan bentuk pemberdayaan santri Pondok Pesantren Al-Furqon Kota Prabumulih melalui kewirausahaan dan pengembangan pemberdayaan santri Pondok Pesantren Al-Furqon Kota Prabumulih melalui kewirausahaan. Penelitian ini menggunakan pendekatan kualitatif dengan melakukan observasi dan wawancara mendalam dengan informan. Pemberdayaan yang diberikan oleh Pondok Pesantren al-Furqon Prabumulih kepada santri dalam bentuk kewirausahaan merupakan salah satu cara dimana selain melatih dan mengembangkan bakat anak, dalam wirausaha juga terdapat nilai-nilai karakter yang dapat mendidik santri menjadi santri yang berkarakter baik. Tidak hanya mampu menjadi seorang wirausaha tetapi dapat sekaligus menjadi orang yang memiliki budi pekerti dan dermawan serta perduli pada lingkungan dan sesama manusia.
\end{abstract}

Keywords: Pemberdayaan Santri, kewirausahaan, pesantren.

\section{Latar belakang}

Pesantren merupakan salah satu lembaga pendidikan yang tertua di Indonesia. Kontribusi yang dimiliki pesantren adalah turut mencerdasakan kehidupan bangsa baik di bidang pendidikan, keagamaan, dan moral. Jika melihat sejarahnya, pesantren mempunyai pengalaman yang sangat luar biasa dalam membina, mencerdaskan, dan mengembangkan masyarakat luas. Bahkan, pesantren mampu meningkatkan perannya secara mandiri dengan menggali potensi yang dimiliki oleh masyarakat di sekelilingnya.

Pesantren telah lama menyadari bahwa pembangunan sumber daya manusia (SDM) bangsa Indonesia tidak hanya menjadi tanggung jawab pemerintah, tetapi juga semua komponen dan lapisan masyarakat, termasuk dunia pesantren. Karena itu, sudah semestinya pesantren yang telah memiliki nilai historis dalam membina dan mengembangkan SDM ini semakin mendorong dan mengembangkan kualitasnya. Pengembangan dunia pesantren ini harus didukung secara serius oleh pemerintah yang terintegrasi dalam sistem pendidikan nasional (Sisdiknas). Mengembangkan peran pesantren dalam pembangunan bangsa Indonesia merupakan langkah strategis dalam memajukan bidang pendidikan.

Pesantren dikembangkan mulai dari konsep "Baiti Jannati" atau rumahku adalah surgaku. Geertz (1986) menuturkan bahwa suasana kehidupan di 
pesantren, sebagai satu kompleks asrama siswa dikelilingi tembok yang berpusat pada suatu masjid. Sedangkan Dhofier (2013) melukiskan unsur-unsur dan suasana pendidikan pesantren yang dianggap sebagai elemen pokoknya adalah; kyai, pondok, masjid, santri dan pengajian kitab klasik. Rumah sekaligus sebagai tempat menimba ilmu

Dengan segala dinamikanya pesantren dipandang sebagai salah satu lembaga yang menjadi pusat awal dimulainya perubahan-perubahan masyarakat. Ia dikenal sebagai lembaga pendidikan non-profit yang memiliki ciriciri khas berprinsip keikhlasan, kesederhanaan, kebersamaan, kekeluargaan, dan kemandirian.

Melalui pembentukan watak dan kemandirian pesantren mampu memegang teguh kemurniannya sebagai lembaga pendidikan Islam. Pesantren tidak mudah disusupi oleh aliran atau paham yang tidak sesuai dengan ajaran Islam. Sedikitnya ada tiga unsur utama penopang eksistensi pesantren dalam pendidikan, yaitu kiai sebagai pendidik, santri sebagai peserta didik, kurikulum pendidikan dan keterampilan. Unsurunsur tersebut mewujud dalam bentuk kegiatannya yang terfokus kepada pembinaan keimanan dan ketakwaan kepada Allah SWT, pengembangan keilmuan dan keahlian yang bermanfaat, serta pengabdian pada agama, masyarakat, dan negara.

Keistimewaan pesantren dalam sistem pendidikan nasional dapat dilihat fungsi pesantren dalam mengembangkan kemampuan dan membentuk watak serta peradaban bangsa yang bermartabat dalam mencerdaskan kehidupan bangsa, bertujuan untuk berkembangnya potensi peserta didik agar menjadi manusia yang beriman dan bertakwa kepada Tuhan
Yang Maha Esa, berakhlak mulia, sehat, berilmu, cakap, kreatif, mandiri, dan menjadi warga negara yang demokratis serta bertanggung jawab.

Saat ini, pesantren mengalami pergeseran nilai yang luar biasa khususnya berkaitan dengan dunia pekerjaan. Dahulu, pesantren masih dianggap tabu jika berbicara tentang pekerjaan atau urusan duniawi apalagi sampai mengembangkan kewirausahaan maka sekarang ini pengembangan kewirausahaan di lingkungan pesantren sudah menjadi kebutuhan apalagi jika hal ini dikaitkan dengan pendidikan pesantren yang mengedepankan kemandirian, kerja keras, disiplin dan jujur. Semua nilai-nilai pendidikan yang dikembangkan pesantren tersebut merupakan jiwa dalam berwirausaha.

\section{Pondok Pesantren Al-Furqon} Kota Prabumulih merupakan salah satu pesantren di Kota Prabumulih yang mempunyai komitmen besar dalam pengembangan kewirausahaan bagi santrinya. Berdasarkan studi pendahuluan dapat diketaui adanya program kewirausahaan bagi para santri dan beberapa unit usaha kewirausahaan yang tersebar di Kota Prabumulih yang pengelolaannya melibatkan para santri. Dengan demikian pesantren Al-Furqon mempunyai peran yang sangat besar dalam mencetak wirausaha muda mandiri.

\section{Metode Penelitian}

Penelitian ini bertujuan untuk menggambarkan dan menemukan pemberdayaan santri Pondok Pesantren Al-Furqon Kota Prabumulih melalui kewirausahaan, maka pendekatan yang digunakan adalah deksriptif kualitatif . Hal ini seperti yang dikemukakan Bungin (2012: 68) bahwa penelitian deskriptif kualitatif adalah suatu peneltian yang 
bertujuan untuk menggambarkan, meringkas berbagai kondisi, situasi, fenomena sosial yang ada di masyarakat yang menjadi obyek Penelitian, dan berupaya menarik realitas tersebut ke permukaan sebagai suatu ciri, karakter, sifat, model, tanda, atau gambaran tentang kondisi tertentu. Pengumpulan data primer dan data sekunder dikumpulkan melalui wawancara mendalam dengan informan kunci yang ditentukan secara purposif dengan kriteria terpilih yang relevan sesuai dengan tema penelitian dan tentunya mereka yang dianggap informan yang dianggap memiliki pengetahuan dan pengalaman pemberdayaan santri melalui kewirausahaan di Pondok Pesantren alFurqon Kota Prabumulih. Sedangkan untuk teknik pemeriksaan yang digunakan hanya menggunakan teknik pemeriksanaan dengan memanfaatkan sumber. Triangulasi dengan sumber adalah memandingkan dan mengecek (cross check) balik derajat kepercayaan suatu informasi yang diperoleh melalui waktu dan alat yang berbeda dalam penelitian kualitatif (Patton, 1987 dalam Moleong, 2012).

\section{Hasil Penelitian}

\subsection{Sejarah Pondok Pesantren A1- Furqon}

Berawal dari pembentukan yayasan, yang selanjutnya bernama Yayasan Pendidikan Pondok Pesantren Modern Al-Furqon Prabumulih, Yayasan ini selanjutnya disahkan oleh Notaris Hamidayati Hamid, SH., pada tanggal 04 Desember tahun 1996, pada masa-masa awal pendiriannya, Yayasan ini mengalami kesulitan untuk melaksanakan Kegiatan Belajar Mengajar (KBM) secara praktis, hal tersebut dikarenakan beberapa hal diantaranya adalah: Masih belum selesainya pembangunan asrama dan lokal pada tahun-tahun pertama, sebab yang lain adalah masih belum adanya SDM yang memadai untuk melaksanakan pendidikan kepesantrenan, meskipun secara materi Pondok Pesantren ini bisa dikategorikan cukup mapan namun untuk memulai palaksanaan KBM tentu belum cukup, oleh sebab itu Pengurus Yayasan mulai mencari tenaga-tenaga pendidik yang profesional dari berbagai daerah di Sumatera Selatan, dan pencarian itupun berakhir setelah Ketua Yasyasan bertemu dengan Ketua Yayasan Pondok Pesantren Assalam Sunagai Lilin MUBA (Ust. H. Abdul Malik Musir, Lc), Memelauli kerja sama yang terjalin maka disepakati bahwa untuuk memulai pelaksanaan KBM maka Ust. Abdul Malik, Lc bertanggung jawab untuk SDM pendidik di Yayasan Pondok Pesantren Modern Al-Furqon Prabumulih.

Dengan telah terpenuhinya syarat minimal untuk pelaksanaan pendidikan kepesantrenan maka Pondok Pesantren Modern Al-Furqon mulai melaksakan KBM secara resmi pada 18 Juli 2002, dan mendapatkan Izin Operasional dari Kantor Wilayah Departemen Agama Sumatera Selatan pada tanggal 07 Oktober 2002, dan Pada tahun inilah awal mula dirintis segala sesuatu yang menjadi kebutuhan masyarakat dalam bidang pendidikan keagamaan. Selanjutnya Pondok Pesantren ini diresmikan oleh Menteri Sosial (Bpk. Bactiar Chamzah) pada tanggal, 08 Maret 2003

Pada awal dimulainya pendidikan di Pesantren ini hanya memiliki, 67 santri, 6 lokal yang dijadikan sebagai tempat belajar 3 ruang, untuk musholla 2 lokal dan untuk kantor 1 lokal. Asrama pemondokan 1 buah yang kemudian di buat dinding pemisah untuk santri putra dan putri. 1 unit dapur dan 1 unit rumah dinas guru (2 pintu). 
Dalam bidang keuangan, Pondok Pesantren Modern Al-Furqon diberi subsidi untuk pemenuhan operasional selama 1 tahun pertama, dan Alhandulillah pada tahun kedua sudah bisa mandiri secara finansial dan tidak lagi disubsidi oleh yayasan dalam pemenuhan operasional. Adapun dalam pemenuhan fasilitas gedung, kendaraan operasional dan lain-lain masih senantiasa mendapatkan subsidi dari pihak Yayasan.

Pada tahun ini (2020) Pondok Pesantren Modern Al-Furqon telah genap berusia 18 tahun meskipun dalam perjalanannya banyak mengalami hambatan dan rintangan, diantaranya adalah: Fasilitas yang belum memadai, jumlah ruang kelas dan asrama yang masih kurang dan masih banyak kekurangan dalam bidang-bidang lain, namun Pondok Pesantren Modern AlFurqon tetap mampu melaksanakan kewajibannya melaksanakan Kegiatan Belajar Mengajar dengan baik, hal ini terbukti dengan keberhasilan alumnialumninya yang telah berhasil melanjutkan pendidikan di perguruan tinggi Negeri maupun Swasta dalam dan luar negeri, secara umum $85 \%$ alumni pondok pesantren modern Al-Furqon melanjutkan ke perguruan tinggi dan sisanya langsung bekerja dan mengabdikan diri di lembaga-lembaga pendidikan. Dalam bidang pemenuhan fasilitas Pondok Pesantren Modern AlFurqon juga senantiasa mengusahakan menambah bangunan, fasilitas dan kendaraan operasional dengan cara melakukan usaha erkebunan, perdagangan, peternakan dan mencari bantuan baik dari pemerintah, dermawan dan lain-lain.

Pada tahun ini, Pondok Pesantren Modern Al-Furqon sedang mengupayakan pemenuhan fasilitas yang sangat mendesak diantaranya:
Menyelesaikan pembangunan masjid putra, menambah lokal belajar sebanyak 3 ruang, membangun asrama putra 1 unit dan membangun kantor.

\subsection{Bentuk Pemberdayaan Santri Pondok Pesantren al-Furqon}

Pemberdayaan

masyarakat merupakan strategi pembangunan. Dalam perspektif pembangunan ini, disadari betapa penting kapasitas manusia dalam upaya meningkatkan kemandirian dan kekuatan internal atas sumber daya materi dan nonmaterial (Muchtar, 2007). Melakukan pemberdayaan masyarakat dapat dilakukan oleh siapa saja kepada masyarakat yang tidak berdaya menjadi berdaya, baik dilakukan secara perseorangan maupun lembaga. Pondok Pesantren al-Furqon Prabumulih merupakan lembaga pendidikan yang dalam pendidikannya tidak hanya memuat pendidikan agama saja, namun santri diberikan pendidikan softskill yang diharapkan dapat berguna ketika santri keluar dari pondok pesantren dan menghadapi kehidupan dunia yang sebenarnya.

Pemberdayaan yang diberikan oleh Pondok Pesantren al-Furqon Prabumulih kepada santrinya dilakukan melalui kewirausahaan yang ada di dalam pondok pesantren. Saat ini, Pondok Pesantren al-Furqon Prabumulih melalukan pengembangan kewirausahaan dengan melibatkan santri. Walaupun kewirausahaan di Pondok Pesantren alFurqon Prabumulih melibatkan santri, pengembangan kewirausahaan ini tidak masuk dalam kurikulum pondok pesantren.

Meskipun kewirausahan tidak dimasukan dalam kurikulum pondok pesantren, akan tetapi Pondok Pesantren al-Furqon Prabumulih tetap memerikan pendidikan kewirausahaan karena 
dianggap sebagai pendidikan yang bersifat lifeskill. Melalui kewirausahan ini diharapkan nantinya santri dapat mempunyai jiwa usahawan.

Bentuk pemberdayaan yang dilakukan di Pondok Pesantren alFurqon Prabumulih pada dasarnya merupakan salah satu bentuk bahwa pondok pesantren tidak hanya mengajarkan ilmu agama saja kepada santrinya. Akan tetapi, Pondok Pesantren al-Furqon Prabumulih juga turut mengembangkan lifeskill yang dimiliki oleh setiap santri yang ada belajar di Pondok Pesantren al-Furqon Prabumulih.

Hasil observasi yang dilakukan oleh peneliti, pemberdayaan yang diberikan oleh Pondok Pesantren alFurqon Prabumulih kepada santrinya ada beberapa bentuk usaha kewirausahaan:

\section{Toko 3 unit}

Saat ini, toko yang dikembangkan untuk kewirausahaan santri Pondok Pesantren al-Furqon ada tiga buah toko. Ketiga toko tersebut berada di dalam kompleks pesantren. Toko ini menyediakan kebutuhan santri selama mereka berada di dalam pesantren. Santri tidak perlu pergi ke luar pesantren untuk membeli keperluan mereka. Toko ini menyediakan peralatan sekolah, buku-buku yang dibutuhkan oleh santri, dan lainnya. Pengelolaan toko ini dilakukan oleh santri yang ikut dalam kegiatan pengembangan kewirausahaan. Para santri yang mengikuti kegiatan kewirausahaan ini diberikan pengetahuan mengenai bagaimana cara melakukan berwirausaha, memanajemen usaha, dan mengembangkan usaha mereka. Uang hasil penjualan kemudian dikumpulkan untuk mengembangkan usaha yang ada di toko tersebut. Pada awalnya, pondok hanya memiliki satu toko saja. Karena jumlah santri bertambah maka pihak pondok pun mengembangkan tokonya. Kewirausahaan yang dikembangkan melalui membuka toko ini diharapkan santri dapat mengetahui cara mengelola sebuah usaha.

2. Perkebunan

Tanah yang dimiliki oleh Pondok Pesantren al-Furqon Prabumulih sangat luas, bahkan masih ada tanah kosong yang belum dibangun untuk pengembangan fasilitas fisik lainnya. Sebelum didirikan Pondok Pesantren al-Furqon Prabumulih, tanah merupakan kebun karet warga yang dibeli oleh pihak yayasan untuk mendirikan pondok pesantren. Pihak yayasan tidak semua menggunakan lahan untuk membangun gedung dan fasilitas pondok pesantren. Pihak yayasan menyisakan beberapa hektar lahan yang diantaranya adalah yang digunakan untuk program pemberdayaan santri melalui pertanian karet. kebun karet yang digunakan untuk program pemberdayaan kewirausahaan santri melalui berkebun karet ini adalah 2 hektar dan sudah ditanami pohon karet yang sudah siap diambil getahnya. Pada usaha perkebunan ini, santri diberikan pengetahuan mengenai cara memilih bibit unggul agar hasilnya tidak mengecewakan, cara memberikan pemupukan, cara memelihara kebun karet, dan cara melakukan memanen getah kareta atau disebut dengan "nako atau mantang". Getah karet yang telah dikumpulkan kemudian disimpan didalam gudang. Setiap satu bulan sekali karet tersebut dijual dan hasil penjualnnya digunakan untuk keperluan pertanian dan disimpan. 
3. Peternakan

Jenis usaha kewirausahaan yang ada di Pondok Pesantren al-Furqon Prabumulih lainnya adalah peternakan kambing dan bebek. Saat ini kambing yang diternakan sebanyak 12 ekor kambing. Sedangkan untuk bebek yang dibudidayakan sebanyak 100 ekor bebek. Santri yang ikut dalam pengembangan usaha peternakan diberi pengetahuan oleh ustadz yang membinanya cara memelihara ternak tersebut mulai dari member makan sampai merawatnya. Hasil dari peternakan kambing jika ada dari pengurus pondok yang membutuhkan untuk berkurban dapat membelinya di peternakan kambing yang dikelola oleh santri. Sedangkan peternakan bebek telurnya dibeli oleh pihak pondok yang kemudian dijadikan sebagai lauk makan santri. Uang hasil penjualan dikembalikan kepada pengelola usaha peternakan yang digunakan untuk operasional peternakan.

4. Perikanan

Perikanan salah satu bentuk pemberdayaan santri melalui kewirausahaan yang dikembangkan di Pondok Pesantren al-Furqon Prabumulih. Saat ini ikan yang dibudidayakan adalah lele. Ada empat kolam ikan lele yang dibudidayakan oleh santri. Satu kolam ikan lele berisi 1.500 ekor lele. santri yang mengelola perikanan lele tersebut. Jika lele tersebut sudah layak untuk di jual maka pihak Pondok Pesantren alFurqon Prabumulih membelinya untuk lauk makan santri. Uang hasil penjualan ikan lele dikembalikan kepada santri yang mengelola kolam lele tersebut untuk operasional perikanan. Pada tahun 2017, Pondok Pesantren al-Furqon Prabumulih akan mendapat bantuan kolam budidaya ikan dari Kementerian Kelautan dan Perikanan. Dari empat lembaga di Sumatera Selatan yang mengajukan, Pondok Pesantren alFurqon Prabumulih salah satu lembaga yang mendapatkan bantuan tersebut. Bantuan tersebut direalisasikan sejak akhir tahun 2017.

5. Pelatihan Mengelas

Pelatihan yang dikembangkan oleh Pondok Pesantren al-Furqon Kota Prabumulih adalah las listrik. Karena mesin yang digunakan cukup dengan menyambungkan dengan aliran listrik maka kegiatan meng-elas berjalan. Di sini, santri diajarkan dasar-dasar mengelas yang baik, cara memotong behel atau besi. Pelatihan mengelas ini hanya diperuntukkan bagi kebutuhan dalam pesantren saja, seperti pembuatan pagar.

6. Kursus komputer

Pelatihan atau kursus komputer pada dasarnya diberikan pada semua santri. Karena santri harus dapat menggunakan komputer. Namun, untuk kegiatan pengembangan kewirausahaan komputer ini tidak semua santri mengikuti kegiatan ini. Kursus komputer diberikan kepada santri yang berminat untuk mengembangkan program komputer. Santri diajarkan beberapa program yang ada dikomputer itu sendiri. Selain itu, santri juga diberikan cara meng-instal program computer dan juga men-service computer jika mengalami kerusakan.

7. Kaligrafi

Pada dasarnya kursus kaligrafi masuk dalam kurikulum yang ada di pesantren. Namun, kursus kaligrafi ini dianggap sebaga bentuk pengembangan kewirausahaan. Santri 
dituntut untuk berinovasi dan berkreasi dalam membuat kaligrafi. Kaligrafi hasil karya santri dapat juga dijual. Jika ada pameran seperti HUT Kota Prabumulih kami memamerkan kaligrafi buatan santri. Pada saat pameran tersebut banyak kaligrafi hasil karya santri dibeli oleh pengunjung. Terkadang, jika ada wali santri yang datang ke pesantren mereka tertarik untuk membeli kaligrafi sanri. Uang hasil penjualan kaligrafi dipergunakan untuk modal dan keperluan pembuatan kaligrafi.

8. Kursus Menjahit

Pondok Pesantren al-Furqon Prabumulih pun memberikan pemberdayaan kepada santri perempuan. Walaupun beberapa bentuk kewirausahaan di atas dapat juga diikuti oleh santri perempuan. Pemberdayaan yang dianggap dapat memberikan pengembangan usaha santri perempuan adalah pelatihan atau kursus menjahit. Bagi santri perempuan yang mengikuti kegiatan kursus menjahit, mereka diberi pelatihan bagaimana cara mengukur, membuat pola baju, memotong pola baju, menjahit baju, dan juga mengobras baju. Pelatihan menjahit ini dibimbing oleh ustadzah yang mengerti cara menjahit. Santriwati diajarkan cara mendisain baju. Kegiatan kursus menjahit ini tentunya memberikan kesempatan kepada santriwati dalam mengembangkan bakat mereka dalam dunia tata busana.

\section{Marketing Day}

Bentuk Pemberdayaan santri melalui kewirausahaan juga ternyata tidak seperti yang disebutkan tadi. Pondok Pesantren al-Furqon Prabumulih juga satu minggu sekali melakukan marketing day. Marketing day adalah suatu kegiatan yang dilakukan oleh santri untuk membuat berbagai macam kuliner. Kegiatan marketing day ini diikuti oleh seluruh santri perempuan dan tiap kelas harus membuat masakan yang kemudian ustadzah yang akan menilainya. Kegiatan marketing day ini dibina oleh ustadzah yang mempunyai keahlian dalam membuat kue atau memasak. Santri diperbolehkan membuat kerativitas dalam membuat makanan. Masakan atau makanan yang dibuat oleh santri tersebut kemudian dijual kepada santri dan pengurus Pondok Pesantren al-Furqon Prabumulih. Kegiatan marketing day ini dapat menumbuhkan bakat yang dimiliki oleh santri perempuan dalam dunia kuliner. Santri dapat berkreasi dan bekerja sama dalam membuat masakan yang akan dibuat.

Semua bentuk kewirausahaan yang dikembangkan oleh Pondok Pesantren al-Furqon Kota Prabumulih bertujuan untuk membentuk karakter santri, mengembangkan kreativitas, dan inovasi santri. Pengembangan lifeskill dapat menanamkan sikap kemandiran yang dimiliki oleh santri. Sikap kemandirian inilah yang nantinya yang menjadi prinsip bagi santri dalam menjalani kehidupan di masyarakat.

\subsection{Pemberdayaan Santri al-Furqon Melalui Kewirausahaan}

Sumodiningrat

(1999:133-134) berpendapat bahwa pemberdayaan masyarakat harus dilakukan melalui 3 (tiga) jalur, yaitu: (1) Menciptakan iklim yang memungkinkan potensi masyarakat berkembang (Enabling); (2) Menguatkan potensi dan daya yang dimiliki masyarakat (Empowering); (3) Memberikan perlindungan (Protecting). Pemberdayaan masyarakat merupakan suatu upaya untuk meningkatkan kemampuan 
masyarakat agar mampu mewujudkan kemandirian dan melepaskan diri dari belenggu kemiskinan serta keterbelakangan.

Pemberdayaan santri Pondok Pesantren al-Furqon Prabumulih pada dasarnya untuk membantu santri dalam mengembangkan softskill yang dimiliki oleh santri. Melalui pemberdayaan kewirausahaan yang dikembangkan santri Pondok Pesantren al-Furqon Prabumulih diharapkan dalam jiwa santri terbentuk sikap kemandirian. Sikap kemandirian merupakan bekal yang harus dimiliki oleh santri ketika mereka menghadapi dunia yang sesungguhnya yang berada di luar pondok pesantren.

Ada tiga fungsi utama yang senantiasa diemban oleh pondok pesantren, yaitu: Pertama, sebagai pusat pengkaderan pmikir-pemikir agama (centre of exellence). Kedua, sebagai lembaga yang mencetak sumber daya manusia (buman resources). Ketiga, sebagai lembaga yang mempunyai kekuatan melakukan pemberdayaan kepada masyarakat (agent of development). Pondok pesantren juga dipahami sebagai bagian yang terlibat dalam peroses perubahan sosial (sosial change) di tengah perubahan yang terjadi (Halim \& Suhartini, 2005).

Partisipasi pesantren dalam pendidikan non formal berbasis perekonomian merupakan salah satu bentuk pembaharuan dalam meminimalisir tingkat pengangguran dari para alumni santri yang sudah menamatkan pendidikannya di pondok pesantren. Para alumni nantinya akan dibekali dengan keterampilan khusus sebagai bekal dalam menjalani kehidupan bermasyarakat. Pondok pesantren dapat mengelola pendidikan kewirausahaan seperti keterampilan pertanian modern, perkebunan, pertukangan, peternakan, perikanan, teknologi informasi dan lainnya, dalam menyiapkan kader alumni sebagai sumber daya insani yang kreatif dan inovatif dalam mengais rezeki setelah menamatkan pendidikannya di pondok pesantren

Pondok Pesantren al-Furqon Prabumulih tidak membatasi para santri untuk mengikuti kegiatan kewirausahaan apapun yang disediakan oleh pesantern, karena itu juga akan menjadi bekal mereka kelak. Memang dampaknya belum terasa ketika mereka masih berada di dalam pesantren. Akan tetapi, itu semua akan berguna ketika mereka berada ditengah masyarakat.

Kegiatan kewirausahaan di Pondok Pesantren al-Furqon Prabumulih sifatnya tidak memaksa dan tidak termasuk dalam kurikulum secara resmi, sehingga para santri diperbolehkan untuk tidak terlibat dalam kegiatan itu, dan tidak dikenakan sanksi secara apapun, akan tetapi ada satu pelatihan yang wajib diikuti oleh para santri, yang pada dasarnya ini hanya untuk sebuah pelatihan dan termasuk dalam kurikulum juga yaitu kaligrafi, kaligrafi itu sendiri bisa juga dijadikan sebagai salah satu bentuk kewirausahaan jika para santri mengkutinya secara serius dan mereka terus melatih kemamapuannya, karena kaligrafi memiliki nilai seni sehingga bisa menghasilkan.

Pemberdayaan yang diberikan oleh Pondok Pesantren al-Furqon Prabumulih kepada santri dalam bentuk kewirausahaan merupakan salah satu cara dimana selain melatih dan mengembangkan bakat anak, dalam wirausaha juga terdapat nilai-nilai karakter yang dapat mendidik santri menjadi santri yang berkarakter baik. Tidak hanya mampu menjadi seorang wirausaha tetapi dapat sekaligus menjadi 
orang yang memiliki budi pekerti dan dermawan serta perduli pada lingkungan dan sesama manusia.

Pada umumnya ketika seorang anak menginjak masa remaja yaitu umur 12 hingga masa remaja akhir pada umur 22, anak memiliki bakat dan minat tertentu yang mulai terlihat. Hal ini biasa disebut sebagai kreativitas anak. Oleh karena itu, untuk mengembangkan bakat kreativitas santri maka Pondok Pesantren al-Furqon melakukan pemberdayaan kepada santrinya dengan membuat program kewirausahaan. Program kewirausahaan yang dikembangkan tersebut akan menjadi nilai tambah yang diberikan pesantren kepada santrinya. Santri bebas memilih bentuk kewirausahaan yang dikembangkan di pesantren sesuai dengan minat dan bakat yang dimiliki oleh santri. Santri boleh memilih lebih dari satu kewirausahaan yang dikembangkan di pesantren.

\section{Pelaksanaan}

kegiatan

kewirausahaan di Pondok Pesantren alFurqon tidak mengganggu kegiatan pembelajaran yang ada di pesantren. Agar tidak tidak mengganggu proses pembelajaran santri selama di pesantren maka waktu pelaksanaan kegiatan kewirausahaan dilaksanakan setelah shalat Ashar dilakukan oleh santri.

Program kewirausahaan bukan merupakan kurikulum inti yang terdapat dalam kurikulum pesantren maka kegiatan kewirausahaan waktunya bersifat lebih longgar dan dilaksanakan setelah shalat Ashar. Setelah shalat Ashar merupakan dimana santri beristirahat. Santri dapat melakukan kegiatan yang sifatnya berinteraksi dengan sesame santri lainnya. Waktu tersebut biasanya diisi dengan bermain sepak bola atau yang lainnya. Bagi santri yang mengikuti kegiatan pemberdayaan kewirausahaan maka mereka pun datang ke lokasi tempat kegiatan kewirausahaannya untuk mengolahnya.

Hasil dari kegiatan kewirausahaan santri ini tentu saja digunakan dan dimanfaatkan oleh pondok, seperti budidaya ikan lele, jika tiba saatnya panen, hasil panen ikan lele ini langsung dimanfaatkan oleh pondok guna menjadi bahan lauk untuk para santri. Tentu saja pihak pondok membelinya dengan harga pasaran guna mengembalikan modal dan untuk budidaya selanjutnya. Ada juga hasil dari kerajinan tangan para santri kita pamerkan ketika ada kegiatan di pondok hasil kerajinan para santri tersebut diminati oleh para wali sanri atau tamu yang datang ke pondok.

Sejalan dengan penelitian Umam (2016) bahwa pelaksanaan program pemberdayaan santri bertujuan untuk memenuhi tuntutan pendidikan, ekonomi, dan dakwah. Manfaatnya dirasakan baik oleh pihak pesantren, santri, orang tua, dan masyarakat sekitar. Pemenuhan tuntutan pendidikan terintegrasinya kurikulum nasional dengan kurikulum pesantren yang melahirkan pendidikan yang terpadu, bukan hanya transfer of knowledge, tetapijuga akhlakul karimah dan kecerdasan di lapangan. Manfaat bagi santri di antaranya memiliki keterampilan yaitu terampil di lapangan, terampil di belakang meja, dan terampil di lapangan. Dalam bidang ekonomi, pesantren mengkhususkan tujuan program pemberdayaannya untuk meringankan beban operasional. Manfaat bagi pesantren adalahh biaya operasional bisa ditekan menjadi lebih rendah. Pesantren mampu menggantikan fungsi pegawai dan fungsi tenaga pengajar oleh santri. Manfaat pada bidang dakwah bagi pesantren diantaranya terjadinya ekspansi yang cepat baik di dalam pesantren 
sendiri maupun pada cabang-cabang yang dibuka oleh alumninya.

\section{Pembahasan}

Pendidikan pesantren dalam menghadapi era globalisasi, meskipun pada awalnya dunia pesantren terlihat enggan dan rikuh dalam menerima perubahan, sehingga tercipta kesenjangan antara pesantren dengan dunia luar. Tetapi secara gradual pondok pesantren kemudian melakukan akomodasi dan konsesi tertentu untuk kemudian menemukan pola yang dipadangnya cukup tepat guna menghadapi perubahan yang kian cepat dan berdampak luas. Dalam hal ini, Pendidikan adalah kehidupan, untuk itu kegiatan belajar harus dapat membekali peserta didik dengan kecakapan hidup (life skill atau life competency) yang sesuai dengan lingkungan kehidupan dan kebutuhan santri.

Respons pondok pesantren terhadap perkembangan tesebut salah satunya dengan diterapkannya pendidikan berbasis kompetensi, dengan semakin banyak memasukkan ketrampilan dan praktek ketrampilan secara nyata dengan dasar pendidikan wirausaha atau enterpreneurship, yang diharapkan bisa membekali santri dengan berbagai kemampuan sesuai dengan tuntutan zaman. Terutama berkaitan dengan kebutuhan masyarakat dan dunia kerja. Walaupun pendidikan wirausahan tersebut tidak dimasukan dalam kurikulum pesantren.

Menyadari hal tersebut maka pengembangan model pendidikan yang harus yang dikembangkan di pondok pesantren Al-Furqan Kota Prabumulih adalah sebuah model pendidikan yang berbasis kompetensi. Pendidikan yang dikelola oleh pondok pesantren mempunyai tugas untuk mengembangkan skill, Knowledge dan
Ability terhadap santri, dengan mengembangkan kompenen-komponen pendidikan yang ada baik dari segi metode, media, materi mapun tenaga edukatifnya.

Untuk dapat memainkan peran edukatifnya dalam penyediaan sumber daya manusia (SDM) yang berkualitas mensyaratkan pesantren harus meningkatkan mutu sekaligus memperbaruhi model pendidikannya. Sebab, model pendidikan pesantren yang mendasarkan diri pada system konvensional atau klasik tidak akan banyak cukup membantu dalam penyediaan sumber daya manusia yang memiliki kompetensi integratif baik dalam penguasaan pengetahuan agama, pengetahuan umum dan kecakapan teknologis. Padahal ketiga elemen ini merupakan prasyarat yang tidak bisa diabaikan untuk konteks perubahan sosial akibat modernisasi. Seperti sekilas diungkapkan dalam latar belakang masalah, tanpaknya tipe ideal model pendidikan pondok pesantren yang dapat dikembangkan saat sekarang ini adalah tipe integrasi antara sistem pendidikan klasik dan sistem pendidikan modern. Pengembangan model pendidikan ini tidak akan merubah total wajah dan keunikan system pendidikan pesantren menjadi sebuah model pendidikan umum yang cenderung reduksionistik terhadap nilai-nilai yang terkandung dalam sistem pendidikan pondok pesantren.

Untuk melahirkan generasi yang mempunyai kompetensi unggul tidak cukup dengan memberikan bekal pengetahuan, namun harus dibarengi dengan kemampuan ketrampilan dengan memanfaatkan potensi dari masyarakat sekitar untuk itu perlu dikembangkan pesantren sebagai berbasis yang mampu mencetak santri-santri yang mempunyai jiwa mandiri dengan mengembangkan 
potensi alam yang ada dan jiwa wirausaha yang tinggi, sehingga lahir santri yang mampu berkiprah baik kemampuan agama, ilmu pengetahuan dan ekonomi.

Kewirausahaan yang ada di Pondok Pesantren al-Furqon Prabumulih merupakan salah satu bentuk kompetensi yang dikembangkan dengan melakukan pemberdayaan kepada santri. pemberdayaan masyarakat merupakan upaya untuk memampukan dan memandirikan masyarakat. Atau dengan kata lain adalah bagaimana menolong masyarakat untuk mampu menolong dirinya sendiri (Suharto, 2004). Pemberdayaan santri melalui pengembangan kewirausahaan dapat menumbuhkan bakat yang ada dalam diri santri. Rich \& Laode (2011) mengatakan bahwa kewirausahaan adalah kemampuan kreatif dan inovatif yang dijadikan dasar, kiat, dan sumber daya untuk mencari peluang menuju sukses. Inti dari kewirausahaan adalah kemampuan untuk menciptakan sesuatu yang baru dan berbeda (creat new and different) melalui berpikir kreatif dan inovatif.

Pendidikan kewirausahaan di pondok pesatren merupakan salah satu usaha dalam menumbuhkan motivasi berwirausaha. Pembelajaran kewirausahaan diharapkan dapat mencetak lulusan santri yang memiliki daya saing profesional, ditandai dengan kemampuan para santri yang memiliki sejumlah keahlian yang tinggi, baik hard skill dan soft skill serta pengetahuan dibidang spiritual, emosional, maupun kreativitas yang menjadi harapan setiap lembaga pondok pesantren. Lulusan santri yang berkualitas dan berdaya saing serta selalu mengedepankan aspek afektif, kognitif dan psikomotorik tentunya akan memiliki nilai yang lebih baik bagi masayarakat dimana para santri tidak sekedar memiliki kemampuan afektif dan kognitif dalam kajian keagamaan semata, akan tetapi juga kemampuan psikomotorik dalam menghadapi dunia kerja maupun menciptakan lapangan usaha sendiri. Oleh karena itu, pelatihan kewirausahaan merupakan pelatihan berbasis kompetemsi (competency-based training) menjadi sangat penting untuk direalisasikan dalam menigkatkan soft skill para santri sebagai bekal saat mereka lulus dari pondok pesantren.

Pengalaman kewirausahaan yang dipelajari santri selama mendalami ilmu di pondok pesantren diharapkan dapat meningkatkan minat berwirausaha pada para santri. Sejalan dengan hasil penelitian yang dilakukan oleh Umam (2016) bahwa pendidikan kewirausahaan merupakan salah satu media dalam memperkenalakan dunia usaha sekaligus memotivasi para santri untuk berwirausaha. Sebagai lembaga pendidikan yang sudah mengakar di masyarkat, keberadaan pesantren memiliki arti penting dalam menyelesaikan problematika perekonomian masyarakat terutama dalam masalah pengangguran dan kemiskinan. Hadirnya pendidikan kewirausahaan di dunia pesantren diharapkan dapat membangun minat para santri untuk menjadi wirausahaan sukses setelah manamatkan pendidikannya di pondok pesantren dengan membuka lapangan kerja baru sebagai solusi dalam mengurangi tingkat pengangguran yang pada akhhirnya akan mensejahterakan dan membangun perekonomian masyarakat sekitarnya. Pendidikan kewirausahaan dipondok pesantren diharapkan dapat memberikan pengalaman dan keterampilan usaha kepada para santri dalam mendorong semangat dan berwirausaha setelah lulus dari pondok pesantren. 
Para santri yang mengikuti pendidikan kewirausahaan dibekali dengan pemahaman bagaimana melakukan suatu usaha, mulai dari perencanaan, analisis kelayakan usaha, pelaksanaan riil, pemberdayaan, pemberian fasilitasi, serta evaluasi dalam setiap kegiatan pendampingan, pemberian pelatihan, motivasi dan semacamnya. Praktek nyata santri dalam kewirausahaan merupakan merupakan penekanan pendidikan kewirausahaan. Sehingga dapat menumbuhkan semangat dan minat para santri dalam berwirausaha.

\section{Kesimpulan}

Setelah peneliti melakukan analisis dan pembahasan mengenai Pemberdayaan Santri Pondok Pesantren Al-Furqon Kota Prabumulih Melalui Kewirausahaan, maka peneliti dapat menyimpulkan bahwa bentuk kewirausahaan yang dikembangkan oleh santri Pondok Pesantren al-Furqon seperti peternakan kambing dan bebek, perikanan budidaya lele, kursus menjahit, kursus komputer, kursus las listrik, perkebunan karet, mengelola toko pesantren, dan marketing day. Bentuk kewirausahaan tersebut sebagai wadah untuk memandirikan para santri.

Pemberdayaan yang diberikan oleh Pondok Pesantren al-Furqon Prabumulih kepada santri dalam bentuk kewirausahaan merupakan salah satu cara dimana selain melatih dan mengembangkan bakat anak, dalam wirausaha juga terdapat nilai-nilai karakter yang dapat mendidik santri menjadi santri yang berkarakter baik. Tidak hanya mampu menjadi seorang wirausaha tetapi dapat sekaligus menjadi orang yang memiliki budi pekerti dan dermawan serta perduli pada lingkungan dan sesama manusia.

\section{References}

Bungin, B. (2012). Penelitian Kualitatif. Jakarta: Kencana.

Halim, A., \& Suhartini, R. (2005). Manajemen Pesantren. Yogyakarta: LKiS.

Moleong, L. J. (2012). Metodology Penelitian Kualitatif. Bandung: PT Remaja Rosdakarya.

Muchtar. (2007). Pemberdayaan Masyarakat Melalui Program Pengembangan Distrik (Kajian Kebijakan dan Implementasinya di Provinsi Papua). Jurnal Penelitian Dan Pengembangan Kesejahteraan Sosial., 12(2).

Rich, \& Laode. (2011). Rasullullah's Business School. Jakarta.

Suharto, E. (2004). Pendekatan Pekerjaan Sosial Dalam Pemberdayaan

Masyarakat Miskin: Konsep, Indikator dan Strategi. Disampaikan Pada Pelatiban Pemberdayaan Masyarakat Miskin Bagi Tenaga Kesejabteraan Sosial Masyarakat, Malang 12 April. Malang.

Sumodiningrat, G. (1999). Pemberdayaan Masyarakat dan Jaring Pengamanan Sosial. Yogyakarta: Ghalia Indonesia.

Umam, K. (2016). Pendidikan Kewirausahaan Di Pesantren Sebagai Upaya Dalam Membangun Semangat Para Santri Untuk Berwirausaha. EKSYAR: Jurnal Ekonomi Syariah, 03(01). 